\title{
Decapodid and early juvenile development in the protandrous shrimp Campylonotus vagans (Crustacea: Decapoda: Caridea), with notes on larval morphology
}

\author{
Sven Thatje $*^{\ddagger}$ and Gustavo A. Lovrich ${ }^{\dagger}$ \\ *Alfred Wegener Institute for Polar and Marine Research, Columbusstrasse, D-27568 Bremerhaven, Germany. \\ ${ }^{\dagger}$ Consejo Nacional de Investigaciones Científicas y Técnicas, Centro Austral \\ de Investigaciones Científicas, CC 92, V9410BFD Ushuaia, Tierra del Fuego, Argentina. \\ ${ }^{\ddagger}$ Corresponding author, e-mail: sthatje@awi-bremerhaven.de
}

\begin{abstract}
The decapodid and first two juvenile stages of the caridean shrimp Campylonotus vagans from the Subantarctic Beagle Channel (Tierra del Fuego, Argentina) are described and illustrated in detail. The complete larval and early juvenile development of this species from rearings under controlled laboratory conditions were analysed. Zoeal morphology in two stages of an abbreviated development was identical to a description from plankton and hatched larvae of a previous work, and therefore we only compare and discuss slight morphological variations in this study. The first juvenile is large and already resembles some features of adults, lacking all ventral rostral and the fourth dorsal rostral spine only which appears in the following stage, and the second pereiopod not yet being as predominant as in adults. Sexual determination is not yet possible up to the described second juvenile stage. The abbreviated larval development in a Subantarctic shrimp species is discussed as an adaptation to low temperatures and pronounced seasonality.
\end{abstract}

\section{INTRODUCTION}

The caridean family Campylonotidae is known to be represented by five species from one genus in the southern hemisphere (Torti \& Boschi, 1973; Thatje, in press). The Subantarctic Magellan species Campylonotus vagans Bate, 1888 and C. semistriatus are known to be distributed in the channel and fjord system of the Magellan region as well as off the continental slope of the south-western Atlantic Ocean of Argentina (Boschi, 1963), whereas the third species, C. capensis, is recorded to prefer deeper waters of the southern Atlantic Ocean (compare with: Torti \& Boschi, 1973; Retamal, 1981; Spivak, 1997; Gorny, 1999; Thatje et al., 2001). Campylonotus rathbunae Schmitt is an archibenthal slope species and the fourth known representative of its genus known to occur in Australasian waters (Yaldwyn, 1960; Pike \& Wiliamson, 1966), and C. arntzianus is the only representative known from Antarctic waters (Thatje, in press).

Apart from some biogeographical data little is known on the life history of these shrimps. Protrandrous hermaphroditism was first described namely for C. rathbunae (Yaldwyn, 1960) and C. semistriatus (Yaldwyn, 1966) and later also discussed to be valid in $C$. vagans and $C$. capensis (Torti \& Boschi, 1973). Knowledge of the early life history is also still scarce, but some morphological differentiation of larval stages and types is possible from the published works of Pike \& Williamson (1966) and Thatje et al. (2001). The latter described larval morphology of the three south Atlantic species, on the basis of larval material obtained from plankton catches mainly. The description of the two zoeal stages of $C$. vagans included the comparison of the Zoea I from the plankton and laboratory hatches, suggesting an abbreviated larval development not exceeding more than three zoeal stages (see Thatje et al., 2001).

In the present work the complete abbreviated larval and early juvenile development in C. vagans obtained under laboratory conditions was analysed. Due to the circumstance that larval development passes through only two zoeal stages which were identical in most aspects to that from the previous description from the plankton (Thatje et al., 2001), the present study just compares and works out morphological differences from both studies. Emphasis is given to the decapodid and the first two shrimp stages which are described in detail.

\section{MATERIALS AND METHODS \\ Capture and maintenance of ovigerous females}

Ovigerous females of Campylonotus vagans were caught at about 15 to $30 \mathrm{~m}$ depth in the Subantarctic Beagle Channel $\left(55^{\circ} \mathrm{S} 68^{\circ} \mathrm{W}\right)$ in September 2001. Samples were taken using an epibenthic trawl of $1.7 \mathrm{~m}$ mouth width and a net with 1-cm mesh size, especially designed to be operated from a small inflatable dinghy. Maintenance of ovigerous females and rearing of larvae took place under constant temperatures of about $7 \pm 0.5^{\circ} \mathrm{C}$ and a salinity of approximately $32 \mathrm{psu}$ in the local institute Centro Austral de Investigaciones Científicas (CADIC) in Ushuaia, Tierra del Fuego, Argentina. 


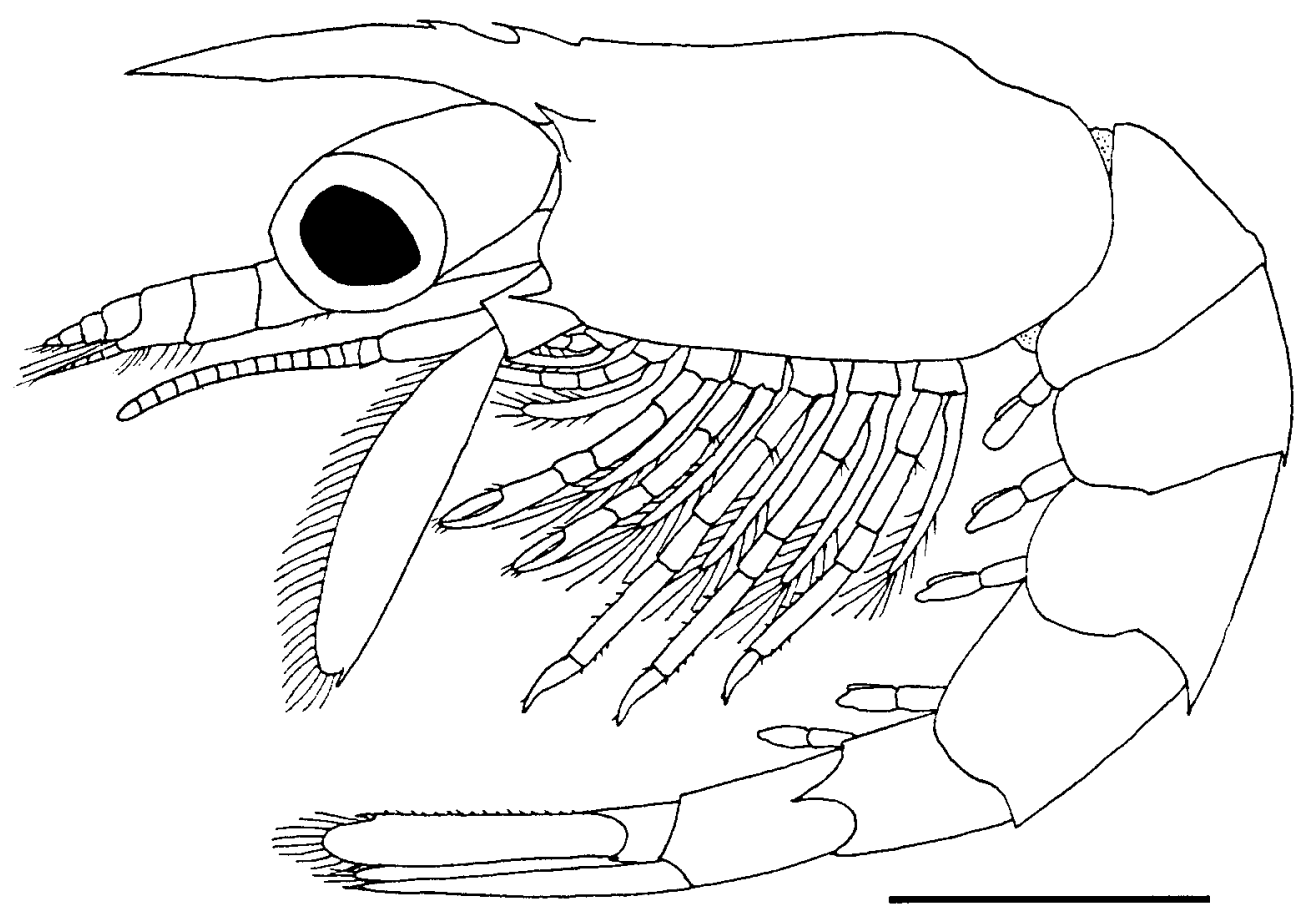

Figure 1. Decapodid stage of Campylonotus vagans, lateral view. Scale bar: $1 \mathrm{~mm}$.

Light and dark phases changed in 12-h-rhythms. Ovigerous females were kept in individual basins with a minimum of $10 \mathrm{l}$ water content with permanent seawater flow from a closed circulation filter system.

\section{Rearing of larvae and juveniles}

First larvae hatched about a fortnight after the capture of ovigerous females. Larvae hatched at night and showed a strong demersal behaviour. Hence, we were not able to make them pass through a waterspout into filter cups using the water circulation system as a tool of separating larvae from the female, in order to avoid cannibalism. Therefore, every night freshly hatched larvae were collected from the bottom of the aquaria using a long glass pipette.

Larvae were randomly selected from the daily hatch and kept in individual cups of $\sim 100 \mathrm{ml}$ seawater content. Larvae were checked daily in order to detect dead or moulting individuals. Water was changed once every two days and, in addition, food was supplied in the form of hatched artemia nauplii (Artemia sp., Argent Chemical Laboratories, USA).

Larvae followed an abbreviated development and passed through two zoeal and a decapodid stage. The separation of the different stages was done on the basis of an existing exuvia and the visual observation of suspicious morphological differences: the second zoeal stage can be easily distinguished by eye from the previous stage by the presence of yet well-developed external uropods (see also Thatje et al., 2001). The decapodid is characterized by fully developed pereiopods bearing reduced exopods and the complete formation of the telson. After fixation in $4 \%$ buffered formalin, carapace (CL) and total lengths (TL) of larvae were measured from the base of the rostrum between the eyes to the posterior dorsal margin of the carapace, and to the posterior margin of the telson respectively.

\author{
RESULTS \\ Campylonotus vagans Bate, 1888 \\ Decapodid \\ (Figures 1-2): $\mathrm{TL}=6.15 \pm 0.04 \mathrm{~mm}$; \\ $\mathrm{CL}=1.75 \pm 0.04 \mathrm{~mm} ; \mathrm{N}=21$
}

Cephalothorax (Figure 1): rostrum straight, smooth, with three dorsal spines at base, posterior one smaller than others. Pterygostomic and supraorbital spines present, both well-developed. Eyes stalked. Antennule (Figure 2A): biramous. Peduncule 3-segmented, first segment with $7+2$ plumodenticulate setae and developed stylocerithe, reduced to a rounded small bud near of base; second and third segments with $4+3$ and $1+2+2$ plumodenticulate setae, respectively. Endopod 5-segmented armed with a lateral, dense row of short simple bristles; apical segment with one pronounced feathered seta and two small simple setae. Exopod 3-segmented with two simple lateral setae at basal segment and 13 aesthetascs, arranged 3, 6, 4 and 1 short apical simple seta. Antenna (Figure 2B): biramous. Protopod unsegmented with one well-developed spine at inner distal end and $2+2$ simple setae at internal lateral margin. Endopod slightly longer than exopod including setation and formed by several segments, but always less than 25. Basal and second segment broader, unarmed and without setae. Exopod (scaphocerite) armed with 31-35 marginal plumose setae. Mandible (Figure 2D): welldeveloped molar and incisor processes, with lacinia mobilis. Palp absent. Maxillule (Figure 2E): coxal and basal endites with 15 plumodenticulate setae each. Endopod 2-segmented, proximal segment with one plumodenticulate seta, distal segment with three terminal plumodenticulate setae, one being longest. Maxilla (Figure 2F): coxal endite bilobed with 36-40 setae, respectively. Basial endite bilobed with seven and ten setae. Endopod unsegmented, 

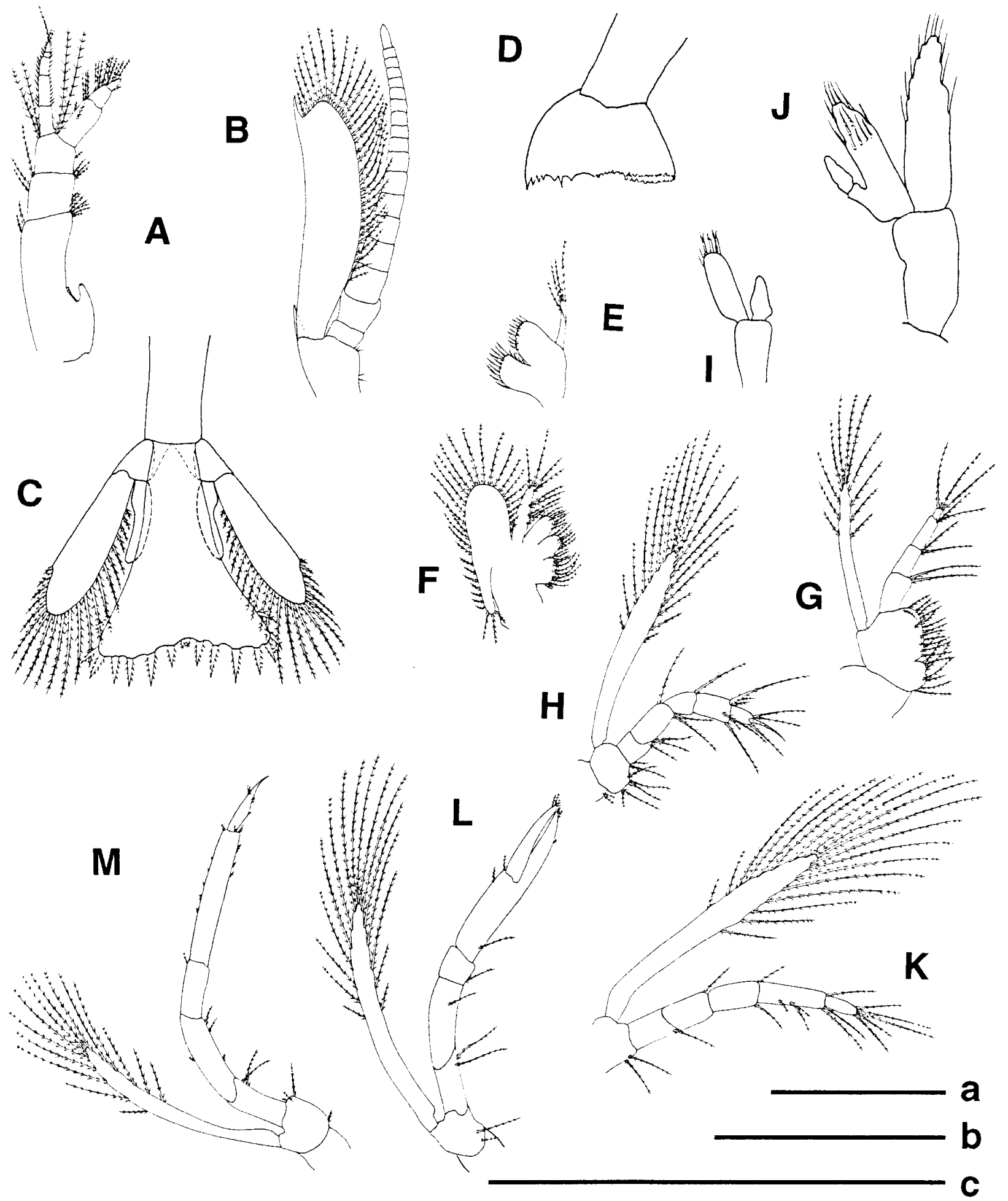

Figure 2. Decapodid stage of Campylonotus vagans: (A) antennule; (B) antenna; (C) telson and uropods, dorsal view; (D) mandible; (E) maxillule; (F) maxilla; $(\mathrm{G})$ maxilliped 1; $(\mathrm{H})$ maxilliped 2; (I) pleopod 1; (J) pleopod 2; (K) maxilliped 3; (L) pereiopod 2; (M) pereiopod 3. Scale bars: a, $1 \mathrm{~mm}$ (Figure, C); b, $1 \mathrm{~mm}$ (Figures, A, B, E-H, K-M); c, $1 \mathrm{~mm}$ (Figures, D, I, J).

with nine plumodenticulate setae, arranged $3+2+4$. Exopod (scaphognathite) with 35-37 marginal plumose setae. Maxilliped 1 (Figure 2G): coxa and basis with 7 and about 30 setae, respectively. Endopod 4-segmented with nine plumodenticulate setae arranged 2, 2, 2, 3. Exopod unsegmented, with 11 long terminal plumose natatory setae. Maxilliped 2 (Figure $2 \mathrm{H}$ ): coxa with two short medial plumodenticulate setae. Basis with seven medial plumodenticulate setae, arranged $2+3+2$. Endopod 5-segmented, with 16 plumodenticulate setae and one apical denticulate strong spine arranged three, $2+1,0+1$, $3+3$ (out of which $1+2$ are reduced in size), three terminal. Exopod unsegmented, with 18 long marginal plumose natatory setae. Epipod present. Maxilliped 3 (Figure 2K): coxa unarmed. Basis with two medial plumodenticulate setae. Endopod 5-segmented, with 15 plumodenticulate setae, arranged $1,0+1,1+1,5+1$ (out of which three are mesial distal ones), five terminal. 


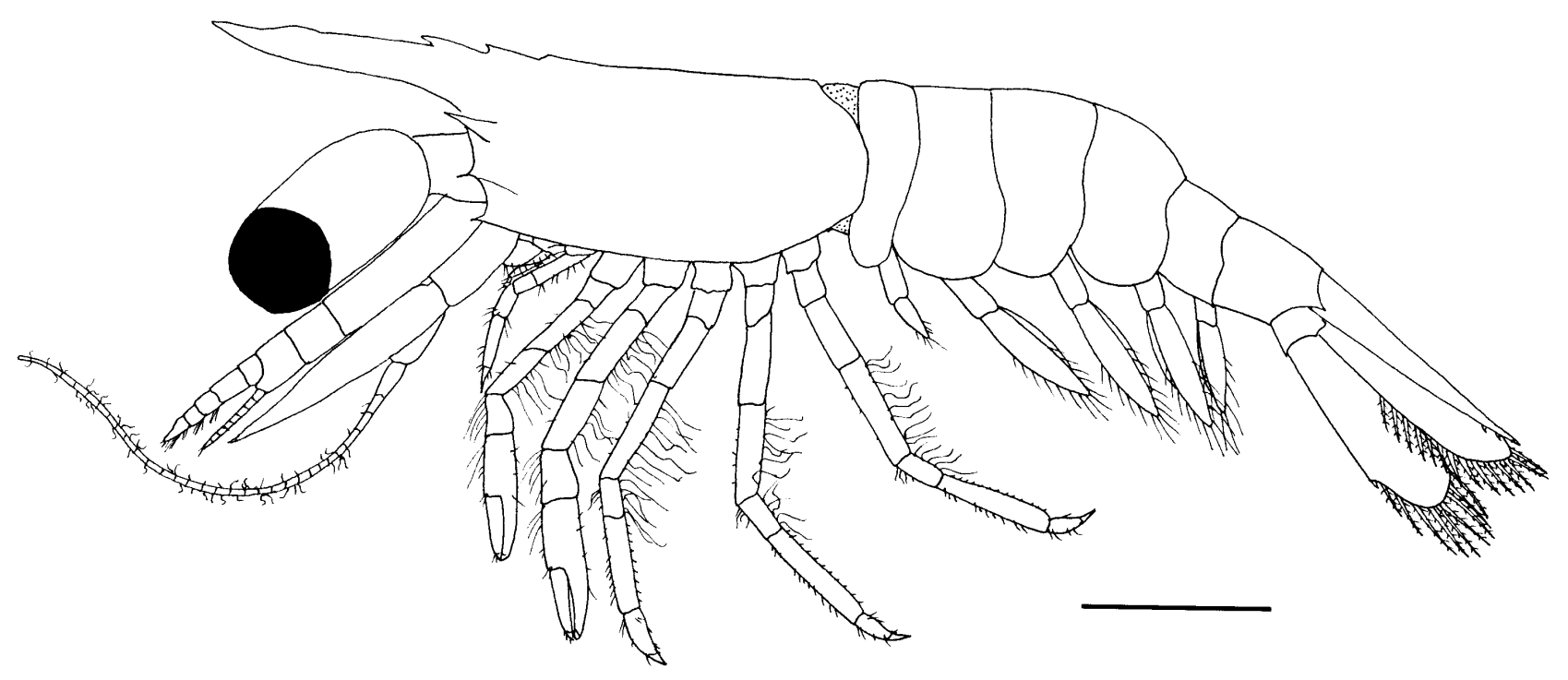

Figure 3. Juvenile I of Campylonotus vagans, lateral view. Scale bar: $1 \mathrm{~mm}$.

Exopod unsegmented, with 18 long marginal plumose natatory setae. Epipod present. Pereiopod 1: coxa unarmed. Basis with two plumodenticulate setae, endopod 5-segmented, ischium, merus, and carpus with two, 1, 1 plumodenticulate setae, respectively; propodus and dactylus as well-developed chela, propodus with $1+2$ plumodenticulate setae; both propodus and dactylus with apical tuft of short plumose setae. Exopod with 16 plumose setae. Pereiopod 2 (Figure 2L): almost the same as in pereiopod 1; endopod as long as exopod including setation, yet being stronger and more pronounced than in pereiopod 1. Pereiopod 3 (Figure 2M): coxa unarmed; basis with $1+3$ (1 being extremely short) plumodenticulate setae; endopod 5 -segmented, ischium merus, carpus and propodus with 2 , $3+1,0+1,5+6$ plumodenticulate setae, respectively; number of short setae along lateral margins of propodus highly variable; dactylus with strong apical slightly curved spine, and $1+2$ short natatory setae at base; propodus with two short mesial spines; exopod slightly longer than ischium and merus combined, with 14 plumose setae. Pereiopods 4 and 5: almost the same as pereiopod 3. Propodus of endopod with variable number of short setae at lateral margins; exopod with 14-16 plumose setae (compare with Figure 2M). Abdomen (Figure 1): six abdominal somites, without ornamentations. Posterolateral margin of somite 5 with conspicuous lateral spine. Pleopods (Figure 2I,J): pleopod 1 with small exopodal bud and endopod being twice as long as exopod; apical margin of endopod with some simple setae and 2-4 stronger feathered setae (Figure 2I). Pleopod 2 with developed endopod and appendix interna; appendix interna shows indication of subdivision; exopod longer than endopod, both with numerous simple setae. Pleopods 3-5 the same. Pleopod 5 slightly shorter than pleopods 2-4. Telson (Figure 2C): triangular with slight medial cleft and eight pairs of well-pronounced processes at inner posterior margin, out of which the inner one is reduced in size, and the outermost situated at distal third of lateral margin. Uropods (Figure 2C): with well-developed exopod and reduced unarmed endopod present; endopod with slight indentation at distal third, and armed with marginal row of long feathered natatory setae.

Juvenile I

(Figures 3 \& 4): $\mathrm{TL}=6.35 \pm 0.07 \mathrm{~mm}$; $\mathrm{CL}=1.95 \pm 0.03 \mathrm{~mm} ; \mathrm{N}=8$

The morphological changes are reported in relation to the previous decapodid stage. Cephalothorax (Figure 3): rostrum straight, smooth, with three dorsal spines at base. Terminal third of rostrum slightly projecting upwards; rostrum dorsally with slight indentations. Pterygostomic and supraorbital spines prominent. Now with orbital spines present. Antennule (Figure 4A): biramous. Peduncule 3 -segmented, first segment with $3+12$ plumodenticulate setae and developed, sharp stylocerithe; second and third segments with $2+5$ and $(1+1+4)+2$ plumodenticulate setae, respectively. Endopod of 8-12 segments, unregularly armed with groups of lateral simple setae; apical segment with two pronounced feathered and two small simple setae. Exopod 5-segmented with two simple lateral setae at basial segment and 15 aesthetascs, arranged 3, 3, 3, 2, 4 plus two short apical simple setae; some simple short setae present at segments. Antenna (Figure 4B): biramous. Protopod bisegmented, without spines. Endopod much longer than exopod (including setation) and of various segments. Basal segment broader, with some simple short setae; endopodal segments densely covered with hairy, irregular long setae and some single short plumodenticulate setae at internal margin. Exopod (scaphocerite) armed with approximately 55 marginal plumodenticulate setae. Mandible (Figure 4D): bearing stronger teeth than in previous stage. No other changes. Maxillule (Figure 4E): coxal and basal endite with numerous short spiny setae. Endopod 3-segmented, medial and distal segment with one aesthetasc each. No other changes. Maxilla (Figure 4F): coxal endite with 15 plumodenticulate setae; basial endite bilobed, with 18-20 setae. Endopod unsegmented, with three plumodenticulate terminal setae. Exopod (scaphognathite) with approximately 40 marginal plumose setae. 


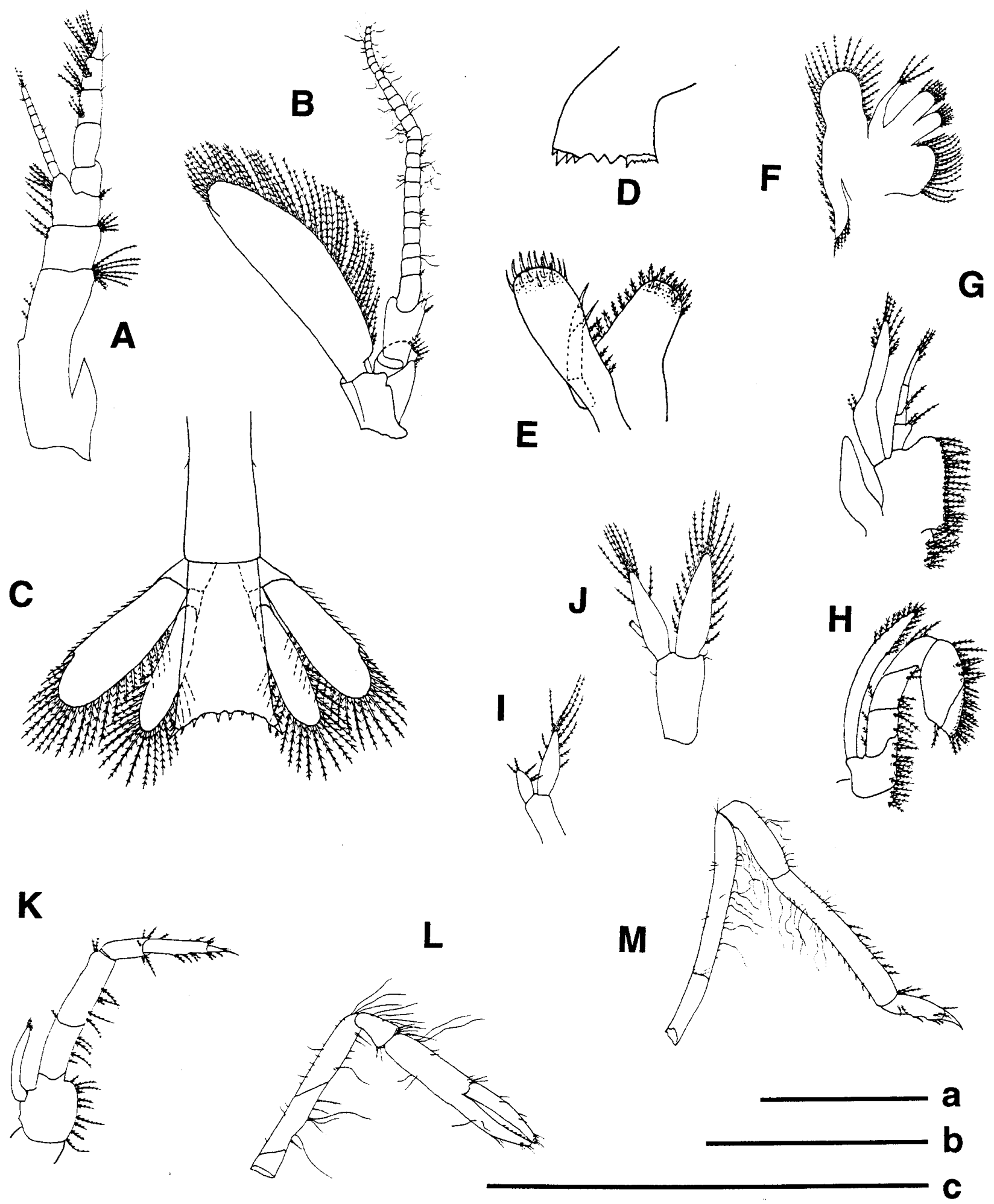

Figure 4. Juvenile I of Campylonotus vagans: (A) antennule; (B) antenna; (C) telson and uropods, dorsal view; (D) mandible; (E) maxillule; (F) maxilla; $(\mathrm{G})$ maxilliped 1; (H) maxilliped 2; (I) pleopod 1; (J) pleopod 2; (K) maxilliped 3; (L) pereiopod 2; (M) pereiopod 3. Scale bars: a, $1 \mathrm{~mm}$ (Figure, C); b, $1 \mathrm{~mm}$ (Figures, A, B, F-M); c, $1 \mathrm{~mm}$ (Figures, D, E).

Maxilliped 1 (Figure 4G): coxa and basis with nine and 33-36 plumodenticulate setae, respectively. Endopod 4-segmented with seven plumodenticulate setae arranged 2, 1, 0, 4 terminal. Exopod unsegmented, broad and reduced, with ten terminal plumose natatory setae and two setae situated at external concave hook. Maxilliped 2 (Figure $4 \mathrm{H}$ ): coxa with six short medial plumodenticulate setae. Basis with 12 plumodenticulate setae. Endopod 5 -segmented, with plumodenticulate setae arranged $4+3$, $5+1,0+2$ in first three segments. Propodus and dactylus now fused to palp, still subsegmented; outer margin fringed with short spinulose setae; propodus distally with one pointing natatory seta. Exopod unsegmented, with 1718 shorter marginal plumose natatory setae, reduced. 
Maxilliped 3 (Figure 4K): coxa unarmed. Basis with about ten plumodenticulate setae. Endopod 5-segmented, with about 28 plumodenticulate setae, arranged $4+1,4+2$, $2+3,6+5,1$, plus one apical and slightly curved projecting spine and 1-2 simple apical setae. Exopod unsegmented and reduced, with apical tuft of short natatory setae remaining. Pereiopods (compare with Figure $4 \mathrm{~L}, \mathrm{M})$ : pereiopods armed with numerous long hairy, thin setae, from merus to propodus, present in varying densities at all pereiopods. Pereiopod 1 (compare with Figure 4L): basis unarmed; endopod 5-segmented, ischium, merus and carpus with numerous plumodenticulate setae, as shown; propodus and dactylus as well-developed chela; both propodus and dactylus with apical tuft of short plumose setae. Exopod absent. Pereiopod 2 (Figure 4L): almost the same as in pereiopod 1; yet being stronger and more pronounced than in pereiopod 1. Pereiopod 3 (Figure 2M): coxa and basis unarmed; dactylus with strong apical slightly curved spine, and several short plumose setae at base. No other changes. Pereiopods 4 and 5: the same as in pereiopod 3. Abdomen (Figure 3): six segments; somites 1-4 with rounded pleura; posterolateral margin of somite 5 with short spine broadening into base. Pleopods (Figure 4I, J): pleopod 1 almost the same as in decapodid stage; apical margin of endopod and exopod now armed with feathered setae (Figure 4I). Pleopod 2 (Figure 4J): exopod now with lateral row of feathered natatory setae; endopod with tuft of feathered apical natatory setae, one pair situated at distal third; endopod with appendix interna. Pleopods 3-5 the same. Uropods (Figure 4C): endopods developed, bearing a simple row of long feathered setae at margin. Telson (Figure 4G): lateral margins of tail fan now almost parallel, slight cleft at posterolateral margin opening wide into rounded margin with outer edges projecting. Posterior margin still with $8+8$ processes, now being shorter, inner one more pronounced than in previous stage, outermost pair of posterolateral margin (6th pair) projecting.

\section{Juvenile II}

(Compare with Figures 3 \& 4): $\mathrm{TL}=7.1 \pm 0.15 \mathrm{~mm}$;

$$
\mathrm{CL}=2.05 \pm 0.07 \mathrm{~mm} ; \mathrm{N}=6
$$

The morphological changes are reported in relation to the previous juvenile I stage. Cephalothorax: rostrum straight, slightly curved up, smooth, with four dorsal spines at base, the last being reduced and unprojected. Antennule: endopod of 10-12 segments, unregularly armed with groups of lateral simple setae; apical segment with two pronounced feathered setae. Exopod 8-segmented with numerous aesthetascs at terminal 5 segments; as long as peduncle. Antenna: endopod much longer than exopod and of various segments, about as long as CL. Maxillule: without changes. Maxilla: setation of endites variable; no other changes. Maxilliped 1: coxa and basis with seven and 30-35 plumodenticulate setae, respectively. Endopod 4 -segmented with eight plumodenticulate setae arranged 2, 2, 0, 3 terminal plus one subterminal. Exopod as reduced bud or absent. Maxilliped 2: setation variable. Exopod as reduced bud or absent. Maxilliped 3: coxa unarmed. Basis with about ten plumodenticulate setae. Endopod 5-segmented, with about 30 plumodenticulate setae, arranged $6+1,4+2,2+3,6+6,0$, plus one apical and slightly curved projecting spine. Exopod absent. Pereiopods: almost the same as in juvenile I. Pereiopods armed with numerous hairy, thin setae, from merus to propodus, present in varying densities at all pereiopods, but being shorter and less dense than in previous stage. Pereiopod 2: now much stronger than in previous stage, compared with pereiopod 1. Abdomen: pleura of somites 2-4 extending; pleura of all somites now armed with minute spines.

\section{DISCUSSION}

In this work we present the morphological description of the postlarval and early juvenile development of the subantarctic shrimp Campylonotus vagans obtained from laboratory rearings. The larval development of $C$. vagans showed a strongly abbreviated development and passed through two zoeal stages and one decapodid only (Thatje et al., 2001).

Although the first two juvenile stages studied were already quite advanced in pleopodal development, a distinct sexual determination was not yet possible. This did not permit the study of the development of protandrous hermaphroditism from its beginning which was described for all four Subantarctic campylonotid species (Yaldwyn, 1966; Torti \& Boschi, 1973).

Thatje et al. (2001) only observed slight variation in TL and CL between larvae hatched from ovigerous females from the Beagle Channel and those obtained from plankton catches in the south-western Atlantic Ocean. Contrastingly, most conspicuous zoeal variability in comparison with our present study was found in both CL and TL, being on an average about 10 to $15 \%$ smaller in our rearings (Zoea I, $\mathrm{N}=29, \mathrm{TL}=5.41 \pm 0.03, \mathrm{CL}=1.43 \pm 0.01$; Zoea II, $\mathrm{N}=13$, $\mathrm{TL}=5.86 \pm 0.02, \mathrm{CL}=1.49 \pm 0.02)$ than in the previous study, regarding both plankton catches and lab cultures of first zoeae. Apart from variability in size, no other conspicuous morphological variations between both studies were found. However, these obvious differences in larval size were already reported in other studies on caridean larvae (Thatje \& Bacardit, 2000; Wehrtmann \& Albornoz, in press). Intraspecific variability in morphology or developmental pathways in caridean larval development is well known from both laboratory and field work (Fincham, 1985; Criales \& Anger, 1986; Thatje \& Bacardit, 2000). Environmental conditions, such as salinity, alimentation or chemical stress in the form of pollution may play an important role affecting phenotypic expression. Temperature was assumed to be most responsible for latitudinal variability resulting in declines in larval instars with latitude (for discussion see: Clarke, 1987, 1993; Thatje \& Bacardit, 2000; Wehrtmann \& Albornoz, in press). These theories on caridean variability in larval development do not necessarily explain the size differences in the present study, since temperature differences are negligible between the southwestern Atlantic and the Beagle Channel $\left(55^{\circ} \mathrm{S} 68^{\circ} \mathrm{W}\right)$ and we found size differences in larvae from the same area (Beagle Channel). Egg size and therefore the energetic investment of energy by females might give further evidence for varying larval sizes. This, on the one hand, might be related to adaptation to latitudinal changes in temperatures (Wehrtmann \& Kattner, 1998) and the need for higher nutrient reserves in areas of primary production 
restricted to short periods, as it is the case in the Subantarctic Beagle Channel. On the other hand, intraspecific competition, the fitness of females as bias of high-energy investment into reproduction, might be seen as an evolutionary tool for successful adaptation to environmental restrictions and changes. To study this we did continuous lipid, protein and $\mathrm{G}, \mathrm{H}, \mathrm{N}$ sampling during our larval rearing which in the future will help to understand the influence of intraspecific variability in terms of initial energetic investment by females.

The abbreviated larval development and hatching of quite advanced larvae in $C$. vagans can be seen as an adaptation to a short primary production period in the Beagle Channel (Antezana \& Hamamé, 1999; Hamamé \& Antezana, 1999). Only one developmental pathway was observed in our rearings and no further instar occurred in one single case (Thatje et al., unpublished data). Variability in larval development in Caridea is assumed to be a successful strategy to respond to changing environmental conditions. However, limited food availability and low temperatures seem to have forced a stronger adaptation in the reproductive strategy in Subantarctic waters, minimizing the loss in energy resources during larval development, such as exuvial loss during moult (Anger, 1984, 1990).

We are indebted to the International Bureau of the German Ministry of Research (BMBF, Arg 99/002) and the Argentine Secretaria Nacional para la Tecnología, Ciencia e Inovación Productiva (SETCIP) for continuous financial support of this bilateral co-operation during the last years. This work was partially financed by the Alfred Wegener Institute for Polar and Marine Research, Bremerhaven, Germany. Our thanks are due to Klaus Anger (Biologische Anstalt Helgoland, Germany) for his great support in this collaboration.

\section{REFERENCES}

Anger, K., 1984. Gain and loss of particulate organic and inorganic matter in larval and juvenile spider crabs (Hyas araneus) during growth and exuviation. Helgoländer Meeresuntersuchungen, 38, 107-122.

Anger, K., 1990. Modelling developmental changes in the carbon and nitrogen budgets of larval brachyuran crabs. Helgoländer Meeresuntersuchungen, 44, 53-80.

Antezana, T. \& Hamamé, M., 1999. Short-term changes in the plankton of a highly homogeneous basin of the Straits of Magellan (Paso Ancho) during spring 1994. Scientia Marina, 63, Supplement 1, 59-67.

Boschi, E.E., 1963. Occurrence of the prawn Campylonotus vagans Bate in the western South Atlantic. Crustaceana, 6, 35-40.

Clarke, A., 1987. Temperature, latitude and reproductive effort. Marine Ecology Progress Series, 38, 89-99.

Clarke, A., 1993. Egg size and egg composition in polar shrimps (Caridea; Decapoda). Journal of Experimental Marine Biology and Ecology, 168, 189-203.
Criales, M.M. \& Anger, K., 1986. Experimental studies on the larval development of the shrimps Crangon crangon and C. allmanni. Helgoländer Meeresuntersuchungen, 40, 241-265.

Fincham, A.A., 1985. Larval development of British prawns and shrimps (Crustacea, Decapoda, Natantia). V. Palaemon (Palaemon) adspersus (Rathke, 1873). Bulletin of the British Museum (Natural History) Zoology, 48, 215-231.

Gorny, M., 1999. On the biogeography and ecology of the Southern Ocean decapod fauna. Scientia Marina, 63, Supplement 1, 367-382.

Hamamé, M. \& Antezana, T., 1999. Chlorophyll and zooplankton in microbasins along the Straits of the MagellanBeagle Channel passage. Scientia Marina, 63, Supplement 1, $35-42$.

Pike, R.B. \& Williamson, D.I., 1966. The first zoeal stage of Campylonotus rathbunae Schmitt and its bearing on the systematical position of the Campylonotidae (Decapoda, Caridea). Transactions of the Royal Society, New Zealand, Zoology, 7, 209-213.

Retamal, M.A., 1981. Catálogo ilustrado de los crustáceos decápodos de Chile. Gayana, Zoología, 44, 1-110.

Spivak, E.D., 1997. Los crustáceos decápodos del Atlántico sudoccidental $\left(25^{\circ}-55^{\circ} \mathrm{S}\right)$ : distribución y ciclos de vida. Investigaciones Marinas, Valparaíso, 25, 73-92.

Thatje, S., in press. Campylonotus arntzianus, a new species of the Campylonotidae (Crustacea: Decapoda: Caridea) from the Scotia Sea (Antarctica). Polar Biology.

Thatje, S. \& Bacardit, R., 2000. Morphological variability in larval stages of Nauticaris magellanica (A. Milne Edwards, 1891) (Decapoda: Caridea: Hippolytidae) from South American waters. Bulletin of Marine Science, 66, 375-398.

Thatje, S., Bacardit, R., Romero, M.C., Tapella, F. \& Lovrich, G.A., 2001. Description and key to the zoeal stages of the Campylonotidae (Decapoda, Caridea) from the Magellan Region. Fournal of Crustacean Biology, 21, 492-505.

Torti, M.R. \& Boschi, E.E., 1973. Nuevos aportes al conocimiento de los crustáceos decápodos Caridea del genero Campylonotus Bate, 1888. Physis, Sección A, Buenos Aires, 32, 65-84.

Wehrtmann, I.S. \& Albornoz, L., in press. Morphological variability in the development of laboratory-reared Nauticaris magellanica (Decapoda: Caridea: Hippolytidae) larvae, with comparison to larvae collected from the plankton. Fournal of the Marine Biological Association of the United Kingdom.

Wehrtmann, I.S. \& Kattner, G., 1998. Changes in volume, biomass, and fatty acids of developing eggs in Nauticaris magellanica (Decapoda: Caridea): a latitudinal comparison. Fournal of Crustacean Biology, 18, 413-422.

Yaldwyn, J.C., 1960. Crustacea Decapoda Natantia from the Chatham Rise; a deep water bottom fauna from New Zealand. Biological Results of the Chatham Island 1954 Expedition. New Zealand Department of Science and Industrial Research, 139, 13-53.

Yaldwyn, J.C., 1966. Protandrous hermaphroditism in decapod prawns of the families Hippolytidae and Campylonotidae. Nature, London, 209, 1366.

Submitted 9 May 2002. Accepted 10 November 2002. 